\title{
Carbon Monoxide (CO)-Induced Hypoxia in Mice: Evaluation as an Experimental Model of Cerebral Ischemia for Drug Screening
}

\author{
Masao KOIDA, Hiromichi NAKAMUTA, Kayoko YASUDA, Keiko MUGURUMA, \\ Yasuzo HIRAMATSU ${ }^{1}$, Yasunao OGAWA ${ }^{1}$ and Yoshikou KATO ${ }^{2}$ \\ Department of Pharmacology. Faculty of Pharmaceutical Sciences and \\ Institute of Drug Safety. Setsunan University. Nagaotoge-cho 45-1. \\ Hirakata 573-01, Japan \\ ${ }^{2}$ Institute of Biological Research. Sawai Pharmaceutical Co., Ltd.. \\ Ikue-cho 1-8-14. Asahi-ku, Osaka 535, Japan
}

Accepted June 26, 1989

\begin{abstract}
An injection of $12.5 \mathrm{ml}$ of carbon monoxide (CO) gas into an air-filled chamber ( $780 \mathrm{ml}$ in volume) caused the death of the ICR or ddY mouse (6-8 weeks old) inside. The average survival time was $2.5 \mathrm{~min}$ for either sex of animals treated with nothing or saline and never exceeded $8 \mathrm{~min}$. Pretreatment with pentobarbital $\mathrm{Na}(30 \mathrm{mg} / \mathrm{kg}$. i.p.), hopantenate $\mathrm{Ca}(100 \mathrm{mg} / \mathrm{kg}$, i.p.), vinpocetine (5 mg/ $\mathrm{kg}$, i.p. or $50 \mathrm{mg} / \mathrm{kg}$, p.o.), flunarizine $\mathrm{HCl}(5 \mathrm{mg} / \mathrm{kg}$, i.p.), glucose $(6 \mathrm{~g} / \mathrm{kg}$, i.p.), phenobarbital $(30 \mathrm{mg} / \mathrm{kg}$. i.p.). phenytoin $(20 \mathrm{mg} / \mathrm{kg}$. i.p.), arginine $\mathrm{HCl}(100 \mathrm{mg} / \mathrm{kg}$. i.p. or $1 \mathrm{~g} / \mathrm{kg}$, p.o.) and alanine $(100 \mathrm{mg} / \mathrm{kg}$, i.p. or $1 \mathrm{~g} / \mathrm{kg}$. p.o.) prolonged the survival time of male mice. Insofar as tested, female mice responded rather poorly to these pretreatments. Survival for longer than $8 \mathrm{~min}$ occurred in some of the drug-pretreated animals of either sex. To be noted is the finding that most of the animals which survived $8 \mathrm{~min}$ once were able to survive the second $8 \mathrm{~min}$ on the following day without any drug-treatment. Monitoring of the time course of carboxyhemoglobin formation revealed that the carboxyhemoglobin level reached a plateau of $70 \%$ saturation within $2 \mathrm{~min}$ and then gradually increased. The lethal level was about $72 \%$. Pentobarbital decreased the formation rate but did not elevate the lethal level. The results indicate that the $\mathrm{CO}$-induced hypoxia model of mice is usable for screening of drug candidates which may be effective for treatment of human ischemic diseases.
\end{abstract}

A variety of cerebral ischemic models of mice have been developed for anti-ischemic drug screening: ligation of bilateral carotid arteries (1), inhalation of hypobaric air $(2,3)$, or normobaric hypoxic air $(2,4-7)$, intravenous injection of $\operatorname{KCN}(2,3)$ and so on. The method of choice would be the ligation method by which one can limit the ischemia to the head, but the reproducibility of the results appears to be low, possibly due to the severe surgical damage. The normobaric hypoxic air method is the most widely used, and it has better reproducibility. Inhalation of hypobaric air or injection of KCN may induce other effects in addition to hypoxia.

Carbon monoxide, a classical asphyxiant, is one of the common causes of world-wide chemical poisoning. The use of gas as the asphyxiant in animal experiments, however, is very limited, though the mechanism of its asphyxic action is principally the same as that of hypoxic hypoxia $(8,9)$ and it may be possible to monitor the hypoxic level of the blood by measuring the degree of saturation of hemoglobin with the gas.

In this experiment, we attempted to evaluate the usability of the $\mathrm{CO}$-inhalation method in screening drug candidates for cerebral ischemic diseases. The experiment consisted of 1) comparison of the "apothanasic" effect of various drugs on $\mathrm{CO}$-induced asphyxia including pentobarbital, and 2) monitoring 
of the time course of the hypoxic level during the gas inhalation and effect of pentobarbital pretreatment. The obtained results indicate the usability of the $\mathrm{CO}$-inhalation method for drug screening.

\section{Materials and Methods}

Six to eight weeks old mice of the ICR and ddY strains (Shimizu Experimental Animals, Kyoto) were used. Chemicals for injection were dissolved in saline, except for vinpocetine which was dissolved in $10 \%$ ascorbic acid solution.

CO-inhalation (10): The mouse was placed on the top of a multi-perforated plastic lid of a petri dish (Sogorikagaku, Kyoto, $87 \mathrm{~mm}$ in diameter and $19 \mathrm{~mm}$ in height) on a glass plate. over which a glass bell jar (Sogorikagaku, Kyoto, $780 \mathrm{ml}$ in volume) was put. The jar was made air-tight using silicone grease, a silicone stopper for the top opening and a gum tubing for tabulation. CO-gas $(99.9 \%$ Japan Oxygen Co., Tokyo) was pressed into a $20 \mathrm{ml}$ syringe; and after adjusting the pressure inside the syringe by taking the needle away for seconds, the gas was injected into the bell jar via a needle through the silicone stopper over a period of $10 \mathrm{sec}$. The air in the jar was mixed by a stirrer bar rotating under the plastic lid. The time from the end of gas injection to respiratory arrest was recorded up to $8 \mathrm{~min}$ as the survival time. Any animal that survived for 8 min was freed from the jar, and in some cases. challenged again on another day. The drug pretreatment was performed 15 min before $\mathrm{CO}$-inhalation for the peritoneal route and $30 \mathrm{~min}$ for the oral route. The room temperature was between 22 and $26^{\circ} \mathrm{C}$.

Spectrophotometric estimation of carboxyhemoglobin level (11): Blood was taken by cardiac puncture using a heparinized needle at various time intervals after $\mathrm{CO}$-gas injection. A $50-\mu l$ blood sample was diluted with $0.1 \%$ $\mathrm{Na}$ carbonate solution (saturated with $\mathrm{N}_{2}$ gas) to $10 \mathrm{ml}$. Ten milligrams of $\mathrm{Na}$ hydrosulfite was dissolved in the blood solution; and $15 \mathrm{~min}$ later, the absorptions at $538 \mathrm{~nm}$ (E538) and at $555 \mathrm{~nm}$ (E555) were measured. When the ratio of $E 538 / E 555$ was $A_{x}$ : the ratio for the blood of the no $\mathrm{CO}$-inhalated animal, $A_{0}$ : and the ratio for the blood saturated with $\mathrm{CO}, \mathrm{A}_{100}$; the carboxyhemoglobin level, $\mathrm{CO}-\mathrm{Hb}(\%)$, was calculated according to the following equation:

$$
\mathrm{CO}-\mathrm{Hb}(\%)=\left(\mathrm{A}_{\mathrm{x}}-\mathrm{A}_{0}\right) /\left(\mathrm{A}_{100}-\mathrm{A}_{0}\right) \times 100
$$

Drugs: Hopantenate $\mathrm{Ca}$ was kindly provided by Tanabe Pharmaceutical Co., Ltd.; Vinpocetine by Takeda Pharmaceutical Co., Ltd: and Flunarizine $\mathrm{HCl}$ by Kyowa Hakko Co., Ltd.

Statistics: The numerical results were expressed as mean \pm S.E.M. Statistical analyses were performed using Student's $t$-test, and differences were considered significant when $P<0.05$.

\section{Results}

1) CO-induced asphyxic death and protection by drugs: In the standard procedure employed herein, $12.5 \mathrm{ml}$ of $\mathrm{CO}$ gas was injected into the jar which was later found to saturate almost $70 \%$ of the hemoglobin within $60 \mathrm{sec}$ (see the saturation curve of the saline-treated control in Fig. 1), and the time from the injection to complete arrest of respiration was recorded up to $8 \mathrm{~min}$. This procedure was set based on the following preliminary observations: i) The average survival time of the naive or saline-treated ICR mice was around $160 \mathrm{sec}$; and saline treatment

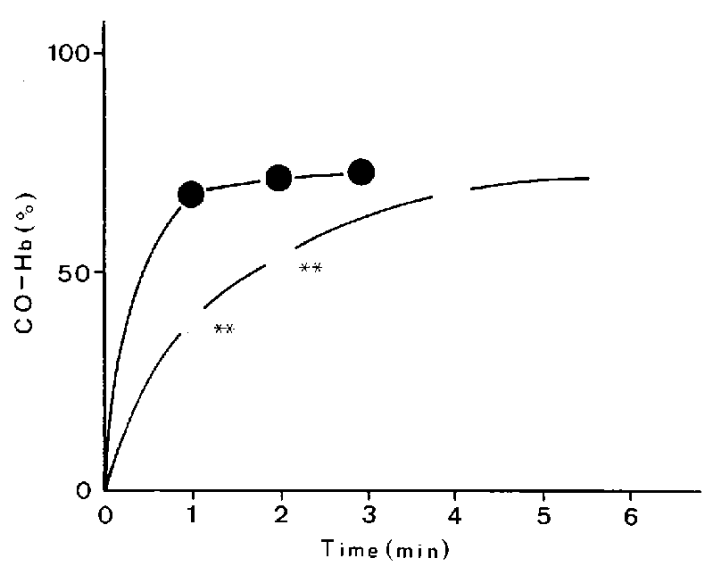

Fig. 1. Time course of carboxyhemoglobin formation during $\mathrm{CO}$ inhalation and effect of pentobarbital. : saline-treated control mice. $\bigcirc$ : pentobarbital $\mathrm{Na}(30 \mathrm{mg} / \mathrm{kg}$. i.p.)-treated mice. Pretreatment was made 15 min before time 0 when CO inhalation was started. **: significantly different from the control $(P<0.01)$. 
tended to elongate the survival time, but never significantly; ii) the increase of gas volume to $15 \mathrm{ml}$ did not change the survival time $(166 \pm 6 \mathrm{sec}, N=9$ to $155 \pm 17 \mathrm{sec}, N=5)$. but a decrease to $10 \mathrm{ml}$ increased both the mean of the survival time and its variance (166 $\pm 6 \mathrm{sec}, N=9$ to $270 \pm 34 \mathrm{sec}, N=5$ ); iii) ddY strain of mice also survived about 160 sec, on the average; iv) the survival time appeared not to differ between male and female ICR mice; and $v$ ) no mice were able to survive longer than 6 min without any drug pretreatment. For setting the maximal survival time as $8 \mathrm{~min}$, the results reported by Von Krieglstein and Hauer (5) was also taken into consideration that NMRI mice survived normobaric hypoxia $\left(3.5 \% \mathrm{O}_{2}\right.$ in $\left.\mathrm{N}_{2}\right)$ for an average time of $180 \mathrm{sec}$ (control 338 mice), and the mean survival time for drug treated groups of mice that survived significantly longer than the control was $528 \mathrm{sec}$ (221 mice). 3 times longer than the control average, though in their study no upper limit for the survival time was set. Thus, all the experiments below were made using ICR mice under the standard procedure.
As shown in Table 1, pentobarbital $\mathrm{Na}$ and hopantenate $\mathrm{Ca}$, glucose, phenobarbital, phenytoin, vinpocetine and flunarizine $\mathrm{HCl}$ were found to elongate the survival time significantly. Of three amino acids tested similarly, arginine $\mathrm{HCl}$ and alanine also delayed the asphyxic death of animals. !n addition, these two amino acids appeared to be active even when pretreated oraliy, but only in higher doses than the ones given intraperitoneally. Though the data are not shown, a lower dose $(100 \mathrm{mg} / \mathrm{kg}$. p.o.) of either amino acid was not effective. Throughout the experiments summarized in Fig. 1, out of 140 mice, 14 showed a survival for longer than 8 min. When each was challenged on the following day, 12 mice were able to survive the 2nd 8 min without any pretreatment.

When compared with male mice. female mice appeared to respond poorly to the tested drugs. Pentobarbital $\mathrm{Na}$. glucose or alanine increased the survival time significantly (Table 2 ), but, here again, 8 min survival was found to occur in most of the drug pretreated groups: and most of the survivors were able to tolerate the 2 nd 8 min as observed with male survivors.

Table 1. Mean survival times of control and drug-treated male mice during CO-inhalation

\begin{tabular}{|c|c|c|c|c|c|}
\hline $\begin{array}{l}\text { Group } \\
\text { No. }\end{array}$ & Treatment & Dose & Route & $\begin{array}{l}\text { Survival time (sec) } \\
\text { mean } \pm \text { S.E.M. }\end{array}$ & $\begin{array}{l}\text { No. of } 8 \text { min survivor/ } \\
\text { No. of animals of group }\end{array}$ \\
\hline 1 & Saline (control) & $10 \mathrm{ml} / \mathrm{kg}$ & i.p. & $154 \pm 17$ & $0 / 8$ \\
\hline 2 & Pentobarbital $\mathrm{Na}$ & $30 \mathrm{mg} / \mathrm{kg}$ & i.p. & $353 \pm 40^{*}$ & $2 / 6$ \\
\hline 3 & Hopantenate $\mathrm{Ca}$ & $100 \mathrm{mg} / \mathrm{kg}$ & i.p. & $217 \pm 11^{*}$ & $0 / 7$ \\
\hline 4 & Glucose & $6 \mathrm{~g} / \mathrm{kg}$ & i.p. & $283 \pm 26^{*}$ & $0 / 7$ \\
\hline 5 & Phenobarbital & $30 \mathrm{mg} / \mathrm{kg}$ & i.p. & $241 \pm 20^{*}$ & $0 / 11$ \\
\hline 6 & Phenytoin & $20 \mathrm{mg} / \mathrm{kg}$ & i.p. & $289 \pm 36^{*}$ & $2 / 11$ \\
\hline 7 & $2 \%$ Ascorbic acid (control) & $10 \mathrm{ml} / \mathrm{kg}$ & i.p. & $190 \pm 20$ & $0 / 7$ \\
\hline 8 & Vinpocetine & $5 \mathrm{mg} / \mathrm{kg}$ & i.p. & $331 \pm 50^{* *}$ & $3 / 8$ \\
\hline 9 & Dist. Water (control) & $10 \mathrm{ml} / \mathrm{kg}$ & p.o. & $163 \pm 11$ & $0 / 6$ \\
\hline 10 & Vinpocetine & $50 \mathrm{mg} / \mathrm{kg}$ & p.o. & $313 \pm 38^{* *}$ & $1 / 6$ \\
\hline 11 & Flunarizine $\mathrm{HCl}$ & $5 \mathrm{mg} / \mathrm{kg}$ & p.o. & $259 \pm 45^{*}$ & $0 / 6$ \\
\hline 12 & Saline (control) & $10 \mathrm{ml} / \mathrm{kg}$ & i.p. & $152 \pm 14$ & $0 / 7$ \\
\hline 13 & Arginine $\mathrm{HCl}$ & $100 \mathrm{mg} / \mathrm{kg}$ & i.p. & $284 \pm 52^{*}$ & $2 / 7$ \\
\hline 14 & Alanine & $100 \mathrm{mg} / \mathrm{kg}$ & i.p. & $267 \pm 53^{*}$ & $2 / 8$ \\
\hline 15 & Glycine & $100 \mathrm{mg} / \mathrm{kg}$ & i.p. & $164 \pm 11$ & $0 / 7$ \\
\hline 16 & Saline (control) & $10 \mathrm{ml} / \mathrm{kg}$ & p.o. & $218 \pm 29$ & $0 / 7$ \\
\hline 17 & Arginine $\mathrm{HCl}$ & $1 \mathrm{~g} / \mathrm{kg}$ & p.o. & $330 \pm 47^{*}$ & $2 / 7$ \\
\hline 18 & Saline (control) & $10 \mathrm{ml} / \mathrm{kg}$ & p.o. & $157 \pm 11$ & $0 / 7$ \\
\hline 19 & Alanine & $1 \mathrm{~g} / \mathrm{kg}$ & p.o. & $261 \pm 36^{*}$ & $0 / 7$ \\
\hline
\end{tabular}

${ }^{*}$ : different from the control $(P<0.05) .{ }^{* *}$ : different from the control $(P<0.01)$. 
Table 2. Means of survival time of contro! and drug-treated female mice during $\mathrm{CO}$-inhalation

\begin{tabular}{|c|c|c|c|c|c|}
\hline $\begin{array}{l}\text { Group } \\
\text { No. }\end{array}$ & Treatment & Dose & Route & $\begin{array}{l}\text { Survival time (sec) } \\
\text { mean } \pm \text { S.E.M. }\end{array}$ & $\begin{array}{l}\text { No. of } 8 \text { min survivorl } \\
\text { No. of animals of group }\end{array}$ \\
\hline 1 & Saline (control) & $10 \mathrm{ml} / \mathrm{kg}$ & i.p. & $188 \pm 14$ & $0 / 16$ \\
\hline 2 & Pentobarbital $\mathrm{Na}$ & $30 \mathrm{mg} / \mathrm{kg}$ & i.p. & $319 \pm 52^{*}$ & $4 / 9$ \\
\hline 3 & Hopantenate $\mathrm{Ca}$ & $100 \mathrm{mg} / \mathrm{kg}$ & i.p. & $232 \pm 69$ & $1 / 6$ \\
\hline 4 & Glucose & $6 \mathrm{~g} / \mathrm{kg}$ & i.p. & $414 \pm 27^{* * *}$ & $6 / 11$ \\
\hline 5 & Dist. water (control) & $10 \mathrm{ml} / \mathrm{kg}$ & p.o. & $173 \pm 23$ & $0 / 6$ \\
\hline 6 & Vinpocetine & $50 \mathrm{mg} / \mathrm{kg}$ & p.o. & $284 \pm 63$ & $1 / 6$ \\
\hline 7 & Flunarizine $\mathrm{HCl}$ & $5 \mathrm{mg} / \mathrm{kg}$ & p.o. & $177 \pm 15$ & $0 / 6$ \\
\hline 8 & Saline (control) & $10 \mathrm{ml} / \mathrm{kg}$ & i.p. & $154 \pm 9$ & $0 / 7$ \\
\hline$\theta$ & Arginine $\mathrm{HCl}$ & $100 \mathrm{mg} / \mathrm{kg}$ & i.p. & $240 \pm 63$ & $2 / 7$ \\
\hline 10 & Alanine & $100 \mathrm{mg} / \mathrm{kg}$ & i.p. & $266 \pm 57^{*}$ & $3 / 8$ \\
\hline 11 & Saline (control) & $10 \mathrm{ml} / \mathrm{kg}$ & p.o. & $158 \pm 15$ & $0 / 6$ \\
\hline 12 & Arginine $\mathrm{HCl}$ & $1 \mathrm{~g} / \mathrm{kg}$ & p.o. & $219 \pm 46$ & $1 / 7$ \\
\hline
\end{tabular}

*: different from the control $(P<0.05)$. "**: different from the control $(P<0.001)$.

2) Time course of carboxyhemoglobin formation and effect of pentobarbital: As illustrated in Fig. 1, the formation of carboxyhemoglobin proceeded rapidly; and in the saline-treated control mice, a $70 \%$ saturation was reached within 2 min. Pentobarbital pretreatment significantly delayed the formation rate: the mean \pm S.E.M. of the saturation levels estimated for the saline-treated control, which survived $178 \pm 12 \mathrm{sec}(\mathrm{N}=8)$ but died before the time set in Fig. 1. was $73 \pm 1.1 \%$, which agreed well with $73 \pm 2.0 \%(N=9)$, the estimate for the drug-treated mice which survived $376 \pm 43 \mathrm{sec}$ but died before the time set. The results show that pentobarbital $\mathrm{Na}$ pretreatment would not affect the lethal level of $\mathrm{CO}$ saturation of hemoglobin.

\section{Discussion}

All the chemicals tested herein for their anti-asphyxic activity except amino acids have already been examined using other mouse models. Table 3 compares our results with some in the literature. Barbiturates including pentobarbital are known to first induce hypothermia, and the resulted hypothermia would prolong the survival time under the hypoxic condition (12). We did not measure the body temperature but the results in Fig. 1 clearly show that pentobarbital $\mathrm{Na}(30 \mathrm{mg}$; $\mathrm{kg}$, i.p.) would exert its "apothanasic" effect by decreasing the rate of gas-exchange by respiration and not by elevating the lethal level of $\mathrm{CO}$-induced asphyxia.

Our results with hopantenate $\mathrm{Ca}$, vinpocetine, flunarizine $\mathrm{HCl}$, phenobarbital and phenytoin are also comparable with those reported by other investigators (Table 3). The protective effect of glucose noted by Von Krieglstein and Hauer (5) in the normobaric hypoxic model was confirmed in this experiment. The attempt to follow the time course of CO-hemoglobin formation failed in glucosetreated mice due to a difficulty in blood sampling which was caused by a high increase in blood viscosity. On the other hand, a possibility that glucose-induced hyperglycemia increases secretion of various hormones including insulin which then could protect mice from asphyxia led us to test the effect of L-arginine, a strong stimulant of insulin and growth hormone secretion (13). The amino acid was found to be active both orally and intraperitonea!ly, but the effective dose by the former route was higher than the one by the latter route, indicating that the $\mathrm{El}$ axis (14) would not practically contribute to the action of the amino acid given orally. On the other hand, a later siudy on microsphereembolized rats provided results suggesting that by post-embolism treatment, the amino acid may be effective in alleviating embolisminduced memory degradation (15).

When the results in Figs. 1 and 2 were compared, it may be noted that female mice tend to respond to various drug treatments rather 
Table 3. Comparison of the protective effects of drugs tested by various mouse models

\begin{tabular}{|c|c|c|c|c|c|}
\hline $\begin{array}{l}\text { Drugs } \\
\text { (reference No.) }\end{array}$ & $\begin{array}{l}\text { Normobaric } \\
\text { hypoxia } \\
(2) \cdot(4-7)\end{array}$ & $\begin{array}{c}\text { Hypobaric } \\
\text { hypoxia } \\
(2,3)\end{array}$ & $\begin{array}{l}\text { Arteries- } \\
\text { ligation } \\
\text { (1) }\end{array}$ & $\begin{array}{l}\text { KCN-injection } \\
(2,3)\end{array}$ & CO-inhalation \\
\hline $\begin{array}{c}\text { Hopantenate Ca } \\
\qquad(1,3)\end{array}$ & & $\begin{array}{l}\text { E. } 250 \text { i.p. } \\
\text { E. } 500 \text { i.p. } \\
\text { E. } 1000 \text { p.o. }\end{array}$ & $\begin{array}{l}\text { E. } 100 \text { i.p. } \\
\text { E. } 100 \text { p.o. } \\
\text { E. } 1000 \text { p.o. }\end{array}$ & $\begin{array}{l}\text { E. } 125 \text { i.p. } \\
\text { E. } 250 \text { i.p. } \\
\text { E. } 500 \text { i.p. }\end{array}$ & E. 100 i.p. \\
\hline $\begin{array}{l}\text { Pentobarbital } \mathrm{Na} \\
\qquad(2,5)\end{array}$ & $\begin{array}{ll}\text { N.E. } & 20 \text { a i.p. } \\
\text { N.E. } & 30 \text { i.p. } \\
\text { E. } & 40 \text { i.p. } \\
\text { E. } & 30 \text { i.p. }\end{array}$ & $\begin{array}{ll}\text { N.E. } & 10 \text { i.p. } \\
\text { E. } & 30 \text { i.p. }\end{array}$ & & E. 80 p.o. & E. 30 i.p. ${ }^{b}$ \\
\hline $\begin{array}{l}\text { Vinpocetine } \\
\qquad(1,4,7)\end{array}$ & $\begin{array}{ll}\text { N.E. } & 1 \text { i.p. } \\
\text { E. } & 2 \text { i.p. } \\
\text { E. } & 5 \text { i.p. } \\
\text { ED } 50= & 16.6 \text { i.p. }\end{array}$ & & $\begin{array}{lr}\text { N.E. } & 2 \text { i.p. } \\
\text { E. } & 20 \text { p.o. } \\
\text { N.E. } & 40 \text { p.o. }\end{array}$ & & $\begin{array}{l}\text { E. } \quad 5 \text { i.p. } \\
\text { E. } 50 \text { p.o. }\end{array}$ \\
\hline $\begin{array}{c}\text { Phenobarbital } \\
\text { (6) }\end{array}$ & ED50=19.8 i.p. & & & & E. 30 i.p. \\
\hline $\begin{array}{r}\text { Phenytoin } \\
\qquad(6)\end{array}$ & $E D 50=13.6$ i.p. & & & & E. 20 i.p. \\
\hline $\begin{array}{l}\text { Flunarizine } \mathrm{HCl} \\
\qquad(1,2)\end{array}$ & $\begin{array}{l}\text { E. } \quad 1 \text { p.o. } \\
\text { E. } \quad 3 \text { p.o. } \\
\text { E. } \quad 10 \text { p.o. }\end{array}$ & $\begin{array}{l}\text { E. } \quad 1 \text { p.o. } \\
\text { E. } \quad 3 \text { p.o. } \\
\text { E. } \quad 10 \text { p.o. }\end{array}$ & $\begin{array}{l}\text { N.E. } 5 \text { i.p. } \\
\text { N.E. } 20 \text { p.o. }\end{array}$ & $\begin{array}{l}\text { E. } \quad 20 \text { p.o. } \\
\text { E. } 40 \text { p.o. } \\
\text { E. } \quad 80 \text { p.o. }\end{array}$ & 5 p.o. \\
\hline
\end{tabular}

a: dose in $\mathrm{mg} / \mathrm{kg}$. b: except this data which was obtained in both sexes, all the other data were from male animals. E: effective and N.E.: not effective.

poorly as compared to male mice, but insofar as concerned with the appearance rate of the $8 \mathrm{~min}$ survivor, there appears to be no sex difference. Another common observation for both sexes was that the animals that survived the first $8 \mathrm{~min}$ by any kind of drug pretreatment were in most cases able to survive at least the $2 \mathrm{nd} 8 \mathrm{~min}$ without any pretreatment in the consecutive daily exposure(s). It is known that chronic tolerance can develop to the toxic action of carbon monoxide in chronically exposed animals and humans, and this is possibly due to polycythemia (16-18). In addition. Winston and Roberts reported that there is a tolerance which could develop in as little as 24 hr (19). It is not clear what kind of tolerance developed in our experiment. Some experiments using the offspring from $8 \mathrm{~min}$ survivors of both sexes are in progress in order to answer this question.

In conclusion, a CO-induced asphyxic animal model tested herein would be usable for screening for a drug candidate with clinical effectiveness for preventing or ameliorating ischemia- or hypoxia-induced disturbances. with at least the advantage that the hypoxic level of the blood can be monitored.

Acknowledgments: The authors express their thanks to Ms. Kyoko Shirai for her excellent secretarial assistance.

\section{References}

1 Takeo, S., Tanonaka, K., Hirano, T., Miyake, K. and Okamoto, J.: Cerebroprotective action of naftidrofuryl oxalate I: Prolongation of survival time and protection of cerebral energy metabolism in bilateral carotid artery-ligated mice. Folia Pharmacol. Japon. 91, 267-273 (1988) (Abs. in English)

2 Karasawa, A., Kumada, Y., Yamada, K., Shuto, $K$. and Nakamizo, N.: Protective effect of flunarizine against cerebral hypoxia-anoxia in mice and rats. J. Pharmacobiodyn. 5, 295-300 (1982)

3 Kudo, Y., Fukuchi, I., Ego, H., Yamamura, M., Kinashi, K., Matsuoka, Y. and Ishida, R.: Pharmacological studies of Ca-Hopantenate (HOPA) in the central nervous system. In Reports of Tanabe Seiyaku Research Laboratories. p. 1424. Tanabe Pharmaceutical Co. Ltd., Osaka 
(1982) (in Japanese)

4 Nagaoka, A., Miyamoto, M., Hamajo, K. and Kiyota, Y.: Protective action of vinpocetine against cerebral ischemia and anoxia. Basic Pharmacol. Ther. 12, 2867-2871 (1984) (Abs. in English)

5 Von Krieglstein, J and Hauer, H.: On the usefulness of a model of acute hypoxia for testing cerebro-protective drugs. Drug Res. 36, 15681571 (1986)

6 King, G.A.: Protection against hypoxia-induced lethality in mice: a comparison of the effects of hypothermia and drugs. Arch. Int. Pharmacodyn. Ther. 286, 282-298 (1987)

7 King, G.A.: Protective effects of vinpocetine and structurally related drugs on the lethal consequences of hypoxia in mice. Arch. Int. Pharmacodyn. Ther. 286, 299-307 (1987)

8 Haldane, J.: The relation of the action of carbonic oxide to oxygen tension. J. Physiol. (Lond.) 18, 201-217 (1985)

9 Roughton, F.J.W. and Darling, R.C.: The effect of carbon monoxide on the oxyhemoglobin dissociation curve. Am. J. Physial. 141, 17-31 (1944)

10 Koida, M., Nakamuta, H., Yasuda, K. and Kato, Y.: Carbon monoxide-induced ischemia death in mice and protective effect of some amino acids. Japan. J. Pharmacol. 46, Supp. 132P (1988)

11 Yuzuriha, C.: A study of carbon monoxide poisoning. A spectrophotometric microdetermination of the CO saturation of the blood hemoglobin and the use of this method in the study of rabbit blood hemoglobin saturated with and dissociated from CO. Fukuoka Acta Med. 50, 224-244 (1959) (Abs. in English)

12 Milde, L.N.: The hypoxic mouse model for screening cerebral protective agents: A reexamination. Anesth. Analg. 67, 917-922 (1988)

13 Daughaday, W.H.: The anterior pituitary. In Textbook of Endocrinology, 7th Ed., Edited by Wilson. J.D. and Foster. D.W., p. 568-613, Saunders, Philadelphia (1985)

14 Jerzy-Glass, G.B.: Gastrointestinal Hormones. Ravan Press, New York (1980)

15 Koida, M., Muguruma, K. and Nakamuta, H.: Carbon monoxide intoxication as a brain ischemic model: Protective effects of some amino acids (II). Folia Pharmacol. Japon. 92, 7P (1988) (in Japanese)

16 Brieger, H.: Carbon monoxide polycythemia. J. Ind. Hyg. Toxical. 26, 321-327 (1944)

17 Wilks, S.S., Tomashefski, J.F. and Clark, R.T., Jr.: Physiological effects of chronic exposure to carbon monoxide. J. Appl. Physiol. 14, 305-310 (1959)

18 Sinith, J.R. and Landaw, S.A.: Smokers polycythemia. N. Engl. J. Med. 298, 6-10 (1978)

19 Winston, J.M. and Roberts, R.J.: Influence of carbon monoxide, hypoxic hypoxia or potassium cyanide pretreatment on acute carbon monoxide and hypoxic hypoxia lethality. J. Pharmacol. Exp. Ther. 193, 713-719 (1975) 